УДК 631.171

DOI: https://doi.org/10.26642/ten-2020-1(85)-104-109

О.М. Свсеснко, к.т.н.

Начіональний технічний університет «Харківський політехнічний інститут»

\title{
Розробка апаратно-програмної системи керування мікрокліматом теплиці
}

На сьогодні, коли населення світу постійно зростає, будь-якій крайні потрібно вирішувати проблему своєчасного забезпечення населення овочами та фруктами високої якості.

Одним із факторів забезпечення країни високоякісними овочами та фруктами вітчизняного виробництва є функціонування тепличного господарства.

Розглянуто основні проблеми ведення та розвитку тепличного господарства в Україні. Наведено основні технічні параметри мікроклімату теплиці. Увесь технологічний процес підтримання мікроклімату розділено на підсистеми за основними типами технологічного прочесу. Розроблено перелік вхідних-вихідних сигналів типової теплиці. Для автоматизації теплиці розроблено структурну схему з використанням контролера Arduino. Для автоматизаціі технологічного процесу підібрано датчики, проміжні реле до виконавчих пристроїв. Наведено вимоги до функиій мобільного додатка для контролю стану мікроклімату теплииі. Запропонована система призначена для автоматизації існуючих теплиць з можливістю запровадження нових розроблених програмних алгоритмів.

У подальших дослідженнях планується впровадження розробленої апаратно-програмної системи для вирощування сільськогосподарських культур у скляних, полікарбонатних та плівкових теплииях. Також планується використовувати розроблену систему для дослідження та побудови моделі теплиці як об'єкта з розподіленими параметрами.

Ключові слова: тепличне господарство; автоматизована система керування; апаратнопрограмний комплекс.

Актуальність теми. Теплиці (рис. 1) є важливою частиною сільськогосподарського і садівничого секторів будь-якої країни, бо використовуються для вирощування рослин у контрольованих кліматичних умовах для максимізації продукції.

Одним із головних факторів, що стримують зростання тепличного господарства в Україні, є висока конкуренція на ринку: імпортні виробники пропонують більший вибір овочів і ягід, які найчастіше виграють і за ціною, і за якістю. Стосовно конкуренції українських овочів, вирощених у теплиці, то вони не витримують конкуренції з імпортними, оскільки останні виявляються дешевшими, навіть із вартістю доставки. 3 початком теплого періоду спостерігається ще і конкуренція 3 південними областями країни, 3 їх тепличними господарствами, які використовують менш затратні прості плівкові теплиці.

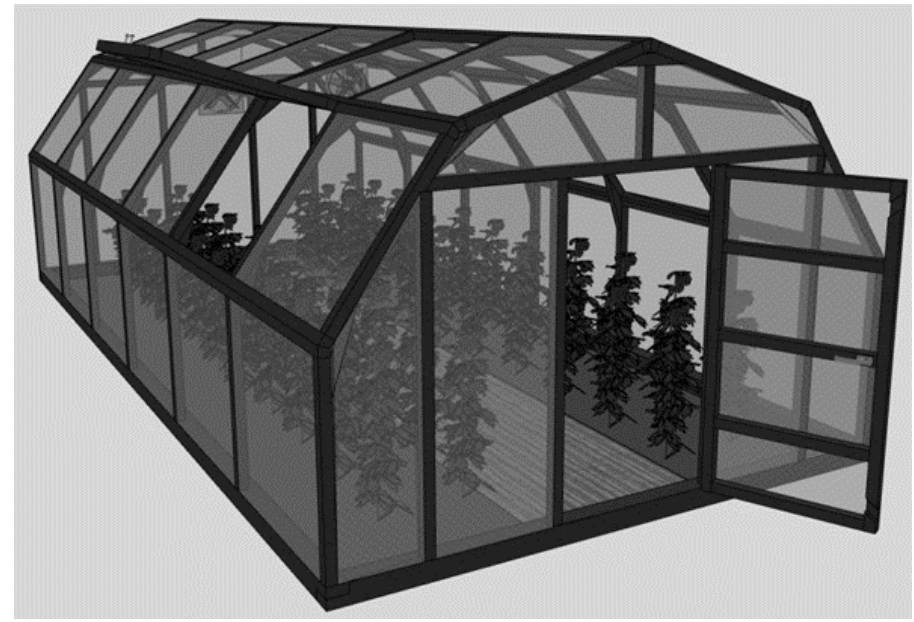

Рис. 1. Зовнішній вигляд скляної теплицฺі

Серед причин, що гальмують розвиток тепличних господарств України та їх прибутковість, - високі ціни на енергоносії, що становлять до 60 \% собівартості у секторі. Тому з кожним роком відбувається скорочення площ теплиць за рахунок зупинки діяльності старих теплиць, у яких неможливо вирощувати продукцію на продаж із помірною собівартістю. У зв'язку з цим розглядається будівництво інноваційних 
енергозберігаючих систем, що дозволяють упорядкувати щорічне споживання газу та диверсифікувати енергоносії іншими альтернативними видами енергії - вугіллям, сонячною енергією, пелетами, біогазом. Пріоритетним вектором у розвитку галузі $\epsilon$ автоматизація і механізація процесів 3 підвищенням енергоефективності, що скоротить собівартість і зробить культури більш конкурентоспроможними на ринках усередині країни.

Сучасні теплиці - це теплиці, які містять мікроконтролери інтернету речей, сенсори, а також програмну частину - систему керування та спеціальний мобільний додаток. Проектами сучасних теплиць передбачено регулювання майже всіх параметрів, що обумовлюють інтенсивний розвиток рослин. Незважаючи на технологічне переоснащення, більшість теплиць досі залишається плівковими, що впливає на якість вирощуваної продукції.

Розвиток тепличного бізнесу безпосередньо залежить від стану сільського господарства країни. Нині Україна має достатній потенціал зростання і перспективи розвитку тепличного господарства. Одним із шляхів виходу з кризи є об'єднання теплиць у одну кооперацію з впровадженням системи керування мікрокліматом.

Аналіз попередніх досліджень. Проблемам побудови систем керування 3 використанням математичних моделей теплиць і розробці регуляторів на основі екстраполятора Сміта та нечіткої логіки присвячено роботи $[1,5]$. Розробці окремого рішення на самостійно створеній платі описано в [2, 3]. У [4] розглянуто проблеми будування систем керування мікрокліматом теплиць. Математичному та комп'ютерному моделюванню розподілу температур розглядається у роботі [6]. Проте в цих дослідженнях не наведено повний перелік та структуру вхідних і вихідних параметрів для побудови системи керування, не виконується концепція інтернету речей - можливість об'єднання декількох теплиць у єдину мережу з виходом до інтернету.

Метою статті с дослідження теплиці як об'єкта автоматизації, складання переліку вхідних і вихідних параметрів для створення мобільного додатка та системи керування мікрокліматом теплиць.

Викладення основного матеріалу. Теплиця містить не тільки металевих каркас i стіни. Найголовніше - це системи зрошення і підтримки мікроклімату. Під мікрокліматом теплиці розуміють штучно створені кліматичні умови для забезпечення оптимального росту i розвитку сільськогосподарських культур.

Автоматизована система управління мікрокліматом має відстежувати кліматичні параметри i керувати виконавчими механізмами, бути легкою в обслуговуванні та експлуатації, дешевою.

Згідно 3 державними будівельними нормами [7] опалення та вентиляція теплиць разом 3 іншими системами мають забезпечувати в них параметри мікроклімату, встановлені вимогами норм технологічного проектування теплиць для вирощування різних видів сільськогосподарської продукції. Розрахункові параметри внутрішнього повітря та температури грунту теплиць варто приймати відповідно до вимог норм технологічного проектування теплиць.

Одним із негативних факторів, що здатний за короткий час погубити всі культури в теплиці, є парниковий ефект. У такій атмосфері швидко починають розвиватися грибкові хвороби, а також утворюється необмежена кількість патогенної мікрофлори в грунті. Захиститися від цього можливо тільки своєчасним провітрюванням теплиць, знижуючи температуру i вологість повітряних мас усередині споруди.

Основні технологічні процеси в теплиці:

1) вентиляція.

Вентиляція $\epsilon$ обов'язковою системою для створення мікроклімату в теплиці. За допомогою вентиляції усувається цвіль і грибкові захворювання рослин, створюється унікальний мікроклімат, необхідний для активного росту рослин. Для вентилювання повітря всередині теплиці в покрівлі передбачаються фрамуги, площа яких становить до 20 \% від загальної площі. Відкриття та закриття фрамуг проводиться за допомогою моторизованих редукторів.

Вентиляція в теплиці здійснюється за допомогою вентиляторів, що створюють переміщення повітря в закритому приміщенні. Вентилятори працюють за двопозиційним законом керування (рис. 2).

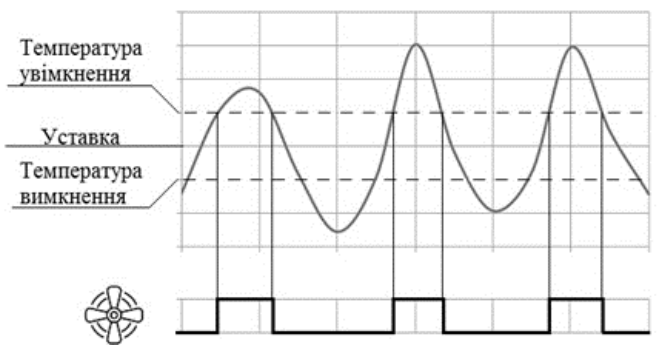

Рис. 2. Закон керування вентиляцієєю в теплицุi 
Вентилятори встановлюються як усередині теплиці, так і зовні. Зовнішні вентилятори потрібні в зимовий період часу, коли не можна відкривати фрамуги через низьку зовнішню температуру, щоб не заморозити рослини. Їх встановлюють у верхній частині теплиць. За допомогою цих вентиляторів холодне повітря потрапляє у верхню частину теплиці, перемішується з гарячим повітрям, таким чином знижуючи температуру в теплиці;

2) освітленість.

Найбільш актуальною проблемою є освітлення в зимовий час, коли світловий день значно коротший. Якщо рослини будуть отримувати світло менше 10 годин на добу, уповільниться їх ріст, що $є$ неприйнятним, особливо для вирощування розсади. 3 цієї причини для забезпечення достатньої освітленості в теплицях застосовують лампи різного типу, що включаються вранці і ввечері, продовжуючи для рослин світловий день. Світлова система є досить дорогою та енергоємною, проте економічно обгрунтованою. Для збільшення ефекту від використання систем освітлення необхідно використовувати додаткові оптичні системи для спрямування освітленості безпосередньо на рослини. Регулювання освітленістю здійснюється за датчиком зовнішнього освітлення, коли поточне значення датчика менше за заданий рівень, або за розкладом;

3) система поливу.

Системи поливу теплиць поділяються на дві групи за принципом подачі води: дощування i крапельний полив.

У першому випадку вода проходить через спеціальні краплеутворюючі пристрої - дощовики, що розбризкують воду на рослини зверху. Автоматичний полив у теплиці, влаштований за принципом крапельної подачі води, більш раціональний, ніж дощування. За такого способу волога ціленаправлено надходить до коріння рослини. Це дозволяє дозовано зрошувати грунт, істотно знижуючи витрату води і електроенергії (порівняно з іншими способами поливу). Кількість точок зволоження не потрібно визначати заздалегідь, їх установлюють залежно від типу грунту і потреби тієї чи іншої культури у волозі. Крапельна автоматична система поливу використовується для внесення кореневого підживлення. Розчинені у воді мінеральні добрива заливають у спеціальні резервуари, що приєднуються до труби [9];

4) обігрів.

Одним із актуальних тепличних питань у холодну пору є обігрів. Найпоширеніші види обігріву тепловентилятори, інфрачервоні обігрівачі, газове опалення. Але найвигіднішим вважають водне опалення.

В обігріві полікарбонатних теплиць добре зарекомендували себе інфрачервоні обігрівачі та «тепла підлога». Це екологічний і нешкідливий спосіб опалення. Він безпечний і для людей, і для рослин.

Основне завдання системи опалення - це підтримка заданої температури. Як правило, опалення теплиці складається 3 декількох роздільних контурів (систем). Регулювання температури повітря для водного опалення здійснюється шляхом зміни температури води в контурах за допомогою клапана, який змішує в необхідній пропорції воду від джерела тепла (прямий теплоносій) 3 водою, яка повернулася 3 теплиці (зворотним теплоносієм) [9].

Температура внутрішнього повітря в теплиці має змінюватися залежно від виду овочів, від часу доби, у процесі росту і дозрівання. Для огірків, наприклад, температура повітря в нічний час має бути близько $18^{\circ} \mathrm{C}$, а в денний час близько $22^{\circ} \mathrm{C}$;

5) розчинний вузол.

При багаторічному вирощуванні овочів поступово погіршується структура тепличного грунту, у ньому накопичується величезна кількість патогенів. Тому підготовка грунту має вирішувати завдання створення оптимального водно-повітряного режиму для живлення рослин, використання органічних добрив та знешкодження його від накопиченої інфекції. За допомогою розчинного вузла готують розчин певної концентрації з оптимальним значенням pН, шляхом змішування з водою маткових розчинів і кислоти;

6) контроль стану повітря.

Повітря містить такі параметри: температура, вологість та рівень СО2. Регулювання температури відбувається за рахунок зовнішнього повітря або за допомогою нагрівачів, якщо температура зовнішнього повітря не підходить. Зволоження здійснюється розпиленням води через форсунки, полив грунту, або використання систем туманоутворення. Однією 3 головних проблем під час використання зовнішнього повітря є контроль точки роси. Для розрахунку температури точки [8] роси Т р використовується (1).

$$
T_{p}=\frac{b \gamma(T, R H)}{a-\gamma(R H)},
$$

де $I_{j}$ - агрегований показник якості професійного судження фахівця;

$a$ - коефіцієнт, що дорівнює 17,27 ;

$b$ - коефіцієнт, що дорівнює $237,7^{\circ} \mathrm{C}$;

$T$ - температура у ${ }^{\circ} \mathrm{C}$;

$R H$ - відносна вологість у об'ємних частках $(0<\mathrm{RH}<1,0)$;

$\gamma(T, R H)$ - розраховується за формулою (2). 


$$
\gamma(T, R H)=\frac{a T}{b+T}+\ln (R H) .
$$

Найважливішим параметром мікроклімату, поряд 3 температурою i вологістю, $\epsilon$ концентрація вуглекислого газу в повітрі. Це пов'язано з тим, що вуглець $є$ основним будівельним матеріалом для рослини і процес фотосинтезу без СО2 неможливий. У деяких випадках доводиться вдаватися до використання рідкої вуглекислоти для підгодівлі, що є дорожчим рішенням.

Виходячи $з$ опису теплиці, принципів і вимог до роботи для підтримки мікроклімату, можна створити такий набір вхідних / вихідних сигналів та сформувати перелік обладнання, що входить до складу системи (табл. 1).

Перелік вхідних/вихідних параметрів та пристрої контролю

Табличя 1

\begin{tabular}{|c|c|c|}
\hline $\begin{array}{c}\text { № } \\
\text { 3/п }\end{array}$ & Параметр & Пристрій \\
\hline 1 & Температура зовнішнього повітря & DS18B20 \\
\hline 2 & Вологість зовнішнього повітря & DHT12 \\
\hline 3 & Сила вітру & RK100-02 \\
\hline 4 & Температура води на вході системи & DS18B20 \\
\hline 5 & Температура води на виході системи & DS18B20 \\
\hline 6 & Температура повітря в теплиці & DS18B20 \\
\hline 7 & Вологість повітря в теплиці & DHT12 \\
\hline 8 & Тиск води на вході системи & SMP2000 \\
\hline 9 & Тиск води на виході системи & SMP2000 \\
\hline 10 & Датчик вологості грунту & FC-28 \\
\hline 11 & Рівень рН & pH Circuit \\
\hline 12 & Відкрити фрамугу & HL-52S \\
\hline 13 & Зачинити фрамугу & HL-52S \\
\hline 14 & Увімкнути освітлення & HL-51 \\
\hline 15 & Увімкнути насос 1 & HL-51 \\
\hline 16 & Увімкнути насос 2 & HL-51 \\
\hline 17 & Увімкнути нагрівач & HL-51 \\
\hline 18 & Рівень СО2 & MH-Z19 \\
\hline 19 & Поточний час & DS3231 \\
\hline & & \\
\hline
\end{tabular}

На підставі обраного обладнання складена структурна схема підключення (рис. 3).

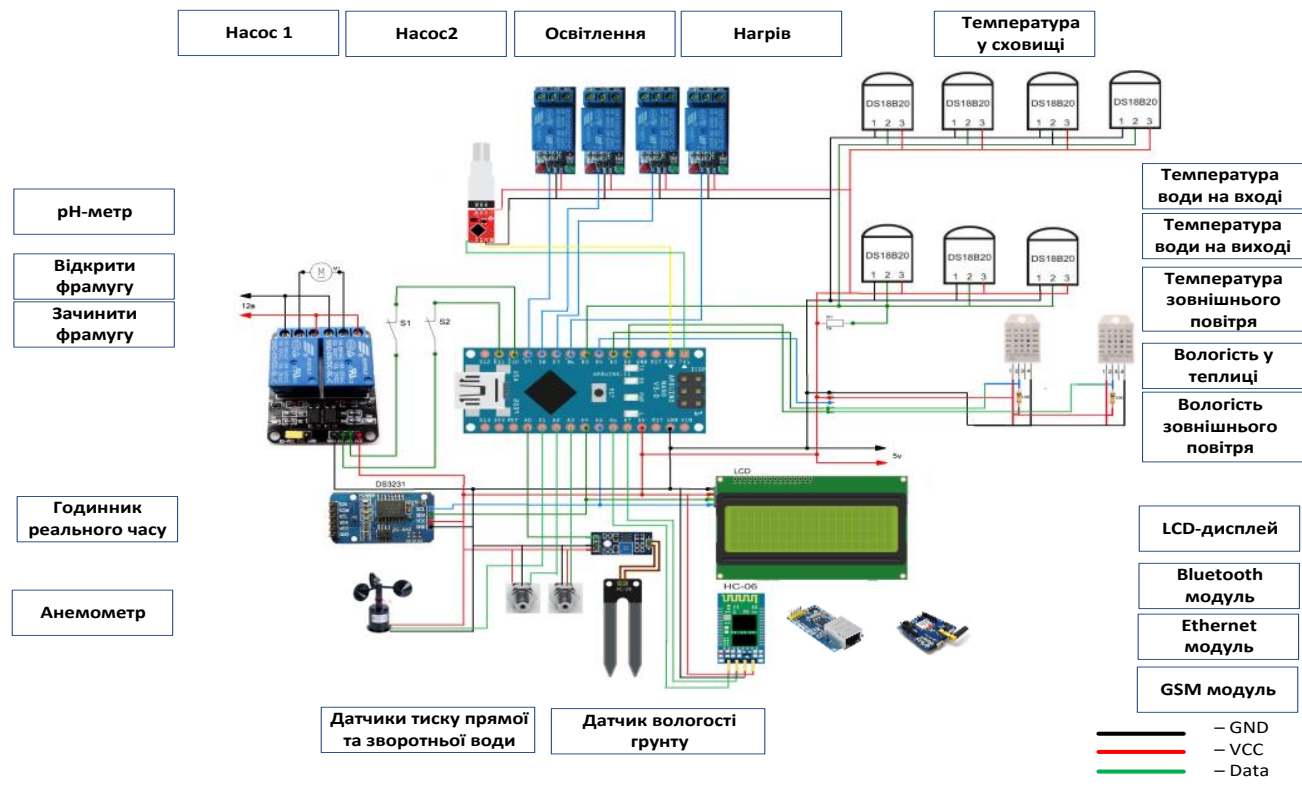

Рис. 3. Структурна схема системи управління мікрокліматом у теплиці 
На сьогоднішній день $з$ розвитком індустрії набуває популярності відображення й управління параметрами різних механізмів за допомогою мобільних додатків. Використовуючи дані в реальному часі від датчиків, додаток дозволяє з'єднуватися і відстежувати умови клімату, отримувати повідомлення про поточні значення параметрів. Для передачі даних можуть використовуватися Bluetooth, ТCP або GSM-модулі.

За допомогою мобільного додатка (рис. 4) можна контролювати температуру, вологість, СО2, рівень $\mathrm{pH}$, поточний стан виконавчих механізмів теплиці тощо. Додаток дозволяє забезпечити доступ до хмарного зберігання всіх даних теплиці, враховуючи історію клімату, аварійні ситуації, тривалість роботи обладнання, журнали доступу.

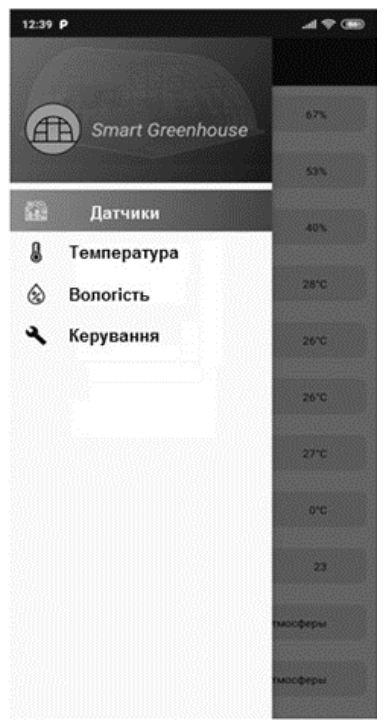

Рис. 4. Меню мобільного додатка

У мобільному додатку мають бути підтримані такі функції:

1. Отримання даних:

а) обробка аналогових та дискретних значень датчиків;

б) обробка штатних подій і сигналів тривоги;

2. Візуалізація процесу роботи у вигляді мнемосхем, індикаторів, графіків, таблиць у зручному для користувача вигляді;

3. Ведення архівів параметрів;

4. Збір та обробка параметрів у реальному масштабі часу;

5. Задання керуючих параметрів регулювання;

6. Вибір законів регулювання для роботи виконавчих механізмів;

7. Відображення подій системи у вигляді Push-повідомлень;

8. Можливість перегляду прогнозу погоди на день, тиждень, місяць;

9. Можливість додавання / видалення датчиків і виконавчих механізмів із додатка;

10. Відображення на дисплеї часу роботи до початку включення механізмів.

Висновки та перспективи подальших досліджень. Зроблено огляд поточного стану теплиць, що дозволило виявити актуальні проблеми стану теплиць в Україні. Проведено огляд типової теплиці як об’екта автоматизації, описано параметри та типовий процес зберігання овочів у теплиці. Складено перелік основних вхідних / вихідних сигналів типової теплиці, що дозволило сформувати вимоги до системи керування та мобільного додатка. Далі планується запровадити розроблену систему керування та створити мобільний додаток для підтримання заданого мікроклімату в теплиці.

\section{Список використаної літератури:}

1. Токмаков H.M. Математическая модель системы управления микроклиматом ангарных теплиц / Н.М. Токмаков, В.С. Грудинин // Гавриш. - 2008. - № 3. - С. 28-32.

2. Jiaqiang Y. An Intelligent Greenhouse Control System / Y.Jiaqiang, J.Yulong, G.Jian // Telkomnika. - 2013. T. 11, № 8. - C. 4627-4632.

3. Віхрова Л.Г. Адаптивна автоматизована система збору та контролю основних параметрів мікроклімату в тепліці / Л.Г. Віхрова, Т.О. Прокопенко // Machinery in agricultural production, industry machine building, automation. - 2016. - № 29. - C. 168-172. 
4. Катков А.Ю. Проблемы построения систем управления микроклиматом теплиц / А.Ю. Катков, И.В. Ползунов, Д.Л. Петрянин // Новые информационные технологии в автоматизированных системах. 2014. - № 17. - С. 460-463.

5. Компьютеризированная система комплексного мониторинга и управления микроклиматом промышленных теплиц на базе нечеткой логики / И.С. Лактионов, А.В. Вовна, М.О. Бережной, В.А. Лебедев // Вісник КрНУ імені Михайла Остроградського. - 2019. - № 3 (116). - С. 120-129.

6. Віхрова Л.Г. Математичне і комп'ютерне моделювання розподілу температур в теплиці для створення системи управління / Л.Г. Віхрова, В.М. Каліч, Т.О. Прокопенко // Техніка в сільськогосподарському виробництві, галузеве машинобудування, автоматизація. - 2011. - № 24, Ч. 2. - С. 174-180.

7. Державні будівельні норми України. Будинки і споруди. Теплиці та парники : ДБН В.2.2-2-95 / Державний комітет України у справах містобудування і архітектури. - Київ, 1995. - 15 с.

8. Dew point [Electronic resource]. - Access mode : https://en.wikipedia.org/wiki/Dew_point.

9. Системы управления микроклиматом теплицы, связь с котельной [Электронный ресурс]. - Режим доступа : http://www.fito-system.ru/climate-systems.

\section{References:}

1. Tokmakov, N.M. and Grudinin, V.S. (2008), «Matematicheskaja model' sistemy upravlenija mikroklimatom angarnyh teplic», Gavrish, No. 3, pp. 28-32.

2. Jiaqiang, Y., Yulong, J. and Jian, G. (2013). «An Intelligent Greenhouse Control System», Telkomnika, Vol. 11, No. 8, pp. 4627-4632.

3. Vihrova, L.G. and Prokopenko, T.O. (2016), «Adaptyvna avtomatyzovana systema zboru ta kontrolju osnovnyh parametriv mikroklimatu $\mathrm{v}$ teplic», Machinery in agricultural production, industry machine building, automation, No. 29, pp. $168-172$.

4. Katkov, A.Ju., Polzunov, I.V. and Petrjanin, D.L. (2014), «Problemy postroenija sistem upravlenija mikroklimatom teplic», Novye informacionnye tehnologii v avtomatizirovannyh sistemah, No. 17, pp. 460-463.

5. Laktionov, I.S., Vovna, A.V., Berezhnoj, M.O. and Lebedev, V.A. (2019), «Komp'juterizirovannaja sistema kompleksnogo monitoringa i upravlenija mikroklimatom promyshlennyh teplic na baze nechetkoj logiki», Visnyk KrNU imeni Myhajla Ostrograds'kogo, No. 3 (116), pp. 120-129.

6. Vihrova, L.G., Kalich, V.M. and Prokopenko, T.O. (2011), «Matematychne i komp'juterne modeljuvannja rozpodilu temperatur v teplyci dlja stvorennja systemy upravlinnja», Tehnika v sil's'kogospodars'komu vyrobnyctvi, galuzeve mashynobuduvannja, avtomatyzacija, No. 24, Part 2, pp. 174-180.

7. Derzh. komitet Ukrai'ny u spravah mistobuduvannja i arhitektury (1995), Derzhavni budivel'ni normy Ukrai'ny. Budynky i sporudy. Teplyci ta parnyky: DBN V.2.2-2-95, Kyi'v, 15 p.

8. Dew point, [Online], available at: https://en.wikipedia.org/wiki/Dew_point

9. Sistemy upravleniya mikroklimatom teplitsy, svyaz' s kotel'noi, [Online], available at: http://www.fitosystem.ru/climate-systems

Свсеєнко Олег Миколайович - кандидат технічних наук, старший викладач Національного технічного університету «Харківський політехнічний інститут».

Наукові інтереси:

- розробка автоматизованих систем керування технологічними процесами.

http://orcid.org/0000-0001-5432-1211.

E-mail: olegyevseienko@gmail.com. 